\title{
MOTIVATIONAL FACTORS INFLUENCING INSTRUCTORS' PERFORMANCE IN THE AGENCY FOR MASS LITERACY, BORNO STATE - NIGERIA
}

\author{
Mshelia Helen Jonathan (Ph.D) \\ Department of Educational Foundations, Faculty of Education, Taraba State University, \\ Jalingo, Taraba State Nigeria. \\ $+2348133695905$
}

\begin{abstract}
This study determined the Motivational Factors that Influenced Instructors' Performance in Agency for Mass Literacy in Borno State, Nigeria. Two research questions and two null hypotheses were formulated in line with the objectives of the study. Survey design was used. The population consists of 229 Instructors. A sample of one hundred(100) Instructors (both male and female) was selected using the random sampling techniques. The instrument used for the study was a self-developed questionnaire by the researcher, tagged "Motivational Factors Influencing Instructor Performance Questionnaire" (MFIIPQ). The questionnaire has twenty seven (27) items. The instrument yielded 0.66 and 0.75 reliability index of internal consistency. Descriptive statistics was used to analyse data collected. Descriptive statistical analysis of percentages and frequency count were used. The study shows that two motivational factors were crucial to Instructors' performance namely: Monetary and Nonmonetary motivation. Based on results of findings, it was recommended (i) that Instructors' monetary benefits must be met as their other counterparts in other sectors. These include: salaries, allowances, gratuity, retirement allowances, health care for Instructors and their families, security with regards to dismissal and retirement. Instructors will be happy if provision for adequate infrastructural facilities (building, furniture, instructional materials and so on) will be made. The Non-monetary benefits include: making Instructors share in policy decision making; Procuring sufficient working tools for Instructors to improve their teaching skills, being attentive to Instructors' material and social problems, listening and appreciating Instructors' views as well as giving equal treatment to all.
\end{abstract}

Keywords: Motivational Factor, Influence, Instructors performance and Mass Literacy. 


\section{Introduction}

Instructors' motivation has become an important issue given their responsibility to impart knowledge, skills and character to learners, and this should begin with mass literacy instructors because the agency is aimed at caring and nourishing reading and writing of adult literacy to enhance holistic academic and social development among full grown adults (Zablon, Benson \& Pamela, 2016). Teachers' motivation is that drive that is exerted on teachers to improve their professional tasks with enthusiasm (Wilson, 2013). Teaching is a noble task that requires keen attention.

According to Sheldon (2013), the relevance of job satisfaction is very crucial to the long term growth of any educational system around the world. They probably rank alongside professional knowledge and skills, centre competencies, educational resources and strategies as the veritable determinants of educational success and performance. Professional knowledge, skills and centre competencies can be seen when one is on and mastering challenging tasks directed at educational success and performance. In addition, needs satisfaction and motivation to work is very essential in the life of teachers because they form the foundation for working in life. While almost every teacher works in order to satisfy his or her needs in life, he or she constantly agitates for the need to satisfaction. Instructor performance in this context is the ability of the teaching job to meet teachers' needs and improve their job/teaching performance (Spector, 2007).

Essa (2010) considers need to be secured within the learners learning environment. Essa stressed that the effectiveness of the teachers depends on the existing levels of motivation as they facilitate enabling and stimulating environment in the foundation of learners to enhance long term development and learning. Ashaky foundation subsequently alters the opportunity for holistic learning and growth.

Zablon et al. (2016) noted that workers are viewed as an asset and are advantaged to an organization or institution. Efforts should to be focused at winning employees' commitment and promote their level of adaptability through communication, motivation and leadership because they are seen to be proactive towards development. Frase (2012) divulged that staff motivation towards effective job satisfaction in Sweden adopted a qualitative approach using ethnography to study 47 Swede teachers. She observed that salary was a strong force that kept teachers on their jobs, hence, it is likely to influence their performance. Additionally, the amount of salary and increments received motivate the teachers when it is paid in time. Similarly, a study by Adams (2009) in Finland on incentives and levels of production among junior staff in Helsinki University established that rewards such as sickness payment, contributory pension schemes, free life insurance and subsidized meals contributed to their job satisfaction.

Justine (2011) opined that employees are the key resources in sustaining the institution's long term competitive advantage, and the ability to attract, maintain, retain and motivate its workforce influences the sustainability of a constant success.

In the 1950s, Frederick Herzberg (Maslow, 1943) proposed a theory of motivation that focused on the job and on the environment where work is done. Herzberg studied various 
factors relating to the job and their relation to employee motivation and concluded that they can be divided into: (i) Hygiene factors and (ii) Motivational factors. Hygiene factors, which relate to the work setting and not the content of the work, include adequate wages, comfortable and safe working conditions, fair company policies, and job security. These factors do not necessarily motivate employees to excel but will definitely have an effect on the employees' performance and their absence may be a potential source of employee dissatisfaction. Hertzberg said, hygiene factors do not motivate. The lack of hygiene factors at work would simply mean that employees are not motivated. Thus, an organization must be conceived with ensuring that both the hygiene factors and motivators are to an adequate standard. It is important to note that with Maslow, the satisfaction or a higher need leads to the next but with Hertzberg, they have two different status factors which are distinct from each other. Status is placed in between motivators and hygiene because when it is achieved, it becomes a motivator and when it is not achieved it becomes a hygiene factor. One major weakness of theories is that it makes no allowance for the different meanings which individuals attach to work or their orientations. Herzberg's theory brought a lot of interest from academics and from managers who were looking for ways of motivating their employees. The reason for so much interest in Herzberg's results comes from a dual character of his work. His theory not only describes employees' needs but also goes further and presents how to enrich jobs and make workforce more motivated. Herzberg indicates that job satisfaction and job dissatisfaction are not opposite phenomena. According to him, the opposite of satisfaction is rather no satisfaction and the opposite of dissatisfaction is no dissatisfaction. Herzberg suggests that satisfaction and dissatisfaction are produced by different factors. People are satisfied at their work by factors related to content of that work. Those factors are called intrinsic motivators and contain achievement, recognition, interesting work, responsibility, advancement and growth. Factors that make people unhappy with their work are called dissatisfiers or hygiene factors. Herzberg found the following as dissatisfiers: company policy, supervision, working conditions, interpersonal relationships, salary, status, security. What makes them different from motivators is the fact that they are not related to the content of the work but to the context of the job. Herzberg results were also attacked because he did not try to measure relationship between performance and satisfaction. As can be seen from this short overview of controversies and overlaps on content theories, not every theory managed to defend itself during decades. However, most of them influenced the growth of interest in the topic of work motivation. Although Herzberg's paradigm of hygiene and motivating factors and Maslow's hierarchy of needs may still have broad applicability in the business world, at least one aspect of each, salary as a hygiene factor (Herzberg) and esteem as a lower order need than self-actualization (Maslow), does not seem to hold in the case of elementary and senior high school teachers. These findings may begin to explain why good teachers are being lost to other higher paying positions and to help administrators focus more closely on the esteem needs of teachers, individually and collectively.

\section{Statement of Problem}

The high rate of illiteracy among adults in Borno state, Nigeria has been of great concern as some of these adults are left embarrassed in the society during public function or interaction where they are unable to relate, articulate or communicate their points and arguments 
effectively. On the other hand, teachers feel dissatisfied and unmotivated in their job performance. In well-motivated schools, teachers are more willing to enhance their teaching skills, exert efforts in the school's activities, as reflected in their participation and commitment where monetary incentives like salaries and wages are paid to the teaching staff; these have great impact on workers' performance in institutions. The provision of motivational factors provides more morale to the workers to remain committed to the organization's set goals, hence, job satisfaction which leads to an increase in participation in the institution's activities for better performance. Based on this, the research would want to find out the factors influencing Instructors' performance in the Agency for Mass Literacy of Borno State, Nigeria.

\section{Purpose of the study}

The purpose of this study is to find out the factors influencing Instructors' performance in the Agency for Mass Literacy of Borno State, Nigeria.

The study intends to determine:

i. The extent to which monetary benefits influence Instructors' performance in the Agency for Mass Literacy of Borno State, Nigeria.

ii. The extent to which non-monetary benefits influence performance of adult education Instructors in the Agency for Mass Literacy of Borno State, Nigeria.

\section{Research Question}

The following research questions guided the researcher in carrying out this study:

i. What are the monetary benefits that influence Instructors' performance in the Agency for Mass Literacy of Borno State, Nigeria?

ii. What are the non-monetary benefits that influence performance of adult education Instructors in the Agency for Mass Literacy of Borno State, Nigeria?

\section{Statement of Hypotheses}

The following null hypotheses are postulated and will be tested at 0.05 level of significance.

i. Monetary benefits related have no significant influence on Instructors' performance in the Agency for Mass Literacy of Borno State, Nigeria.

ii. Non- monetary benefits have no significant influence on Instructors' performance in the Agency for Mass Literacy of Borno State, Nigeria.

0

\section{Methodology}

The research design adopted for this study was survey design. This is because it determined the motivational factors that could influence Instructors' performance in the Agency for Mass Literacy of Borno State, Nigeria. The target population for this study comprised of all Instructors who are permanent and pensionable staff of the Agency for Mass Literacy of 
Borno State. A total of 100 Instructors constituted the sample of the study. This include, 60 males and 40 female Instructors. Simple random sampling was used in selecting the subjects for the study.

The researcher developed an instrument for data collection for the study titled: Instructor Factor Questionnaire with 27 item based on 5 point likert rating scale.

To ensure validity and reliability of instrument, 3 expert reviewed the instrument based on face and content validity. To determine the reliability, the instrument was pilot tested using test retest method and computed using the Pearson Product Moment Correlation (PPMC) where a positive significant correlation of 0.66 was obtained and the retest had the value of 0.75 .

\section{Results}

Research question 1: what are the monetary benefits that influence Instructors' performance in the Agency for Mass Literacy of Borno State, Nigeria?

Table 1: Frequency/percentage distribution of respondents on monetary benefit.

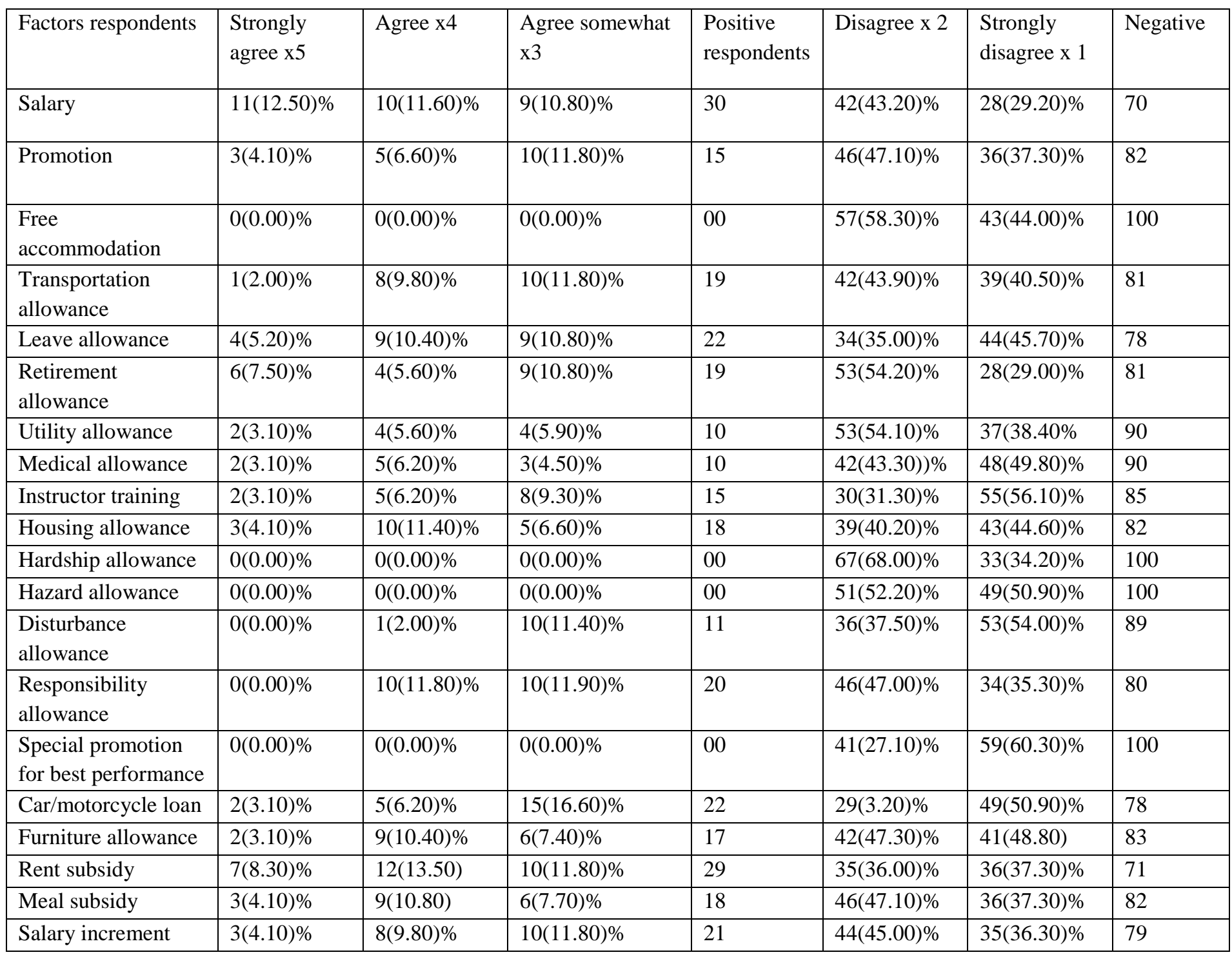


Research question 2: What are the non-monetary benefits that influence performance of adult education Instructors in the Agency for Mass Literacy of Borno State, Nigeria.

Table 2: Frequency/percentage distribution of respondents on non-monetary benefit.

\begin{tabular}{|c|c|c|c|c|c|c|c|}
\hline Factors & $\begin{array}{l}\text { Strongly } \\
\text { agree x } 5\end{array}$ & Agree $x 4$ & $\begin{array}{l}\text { Agree } \\
\text { somewhat x3 }\end{array}$ & $\begin{array}{l}\text { Positive } \\
\text { respondents }\end{array}$ & Disagree $\mathrm{x} 2$ & $\begin{array}{l}\text { Strongly } \\
\text { disagree x } 1\end{array}$ & Negative \\
\hline $\begin{array}{l}\text { Instructors } \\
\text { actively } \\
\text { participation } \\
\text { in policy } \\
\text { decision } \\
\text { making in the } \\
\text { Agency }\end{array}$ & $0(0.00) \%$ & $8(9.00) \%$ & $20(21.00) \%$ & 48 & $43(45.20) \%$ & $29(30.40) \%$ & 72 \\
\hline $\begin{array}{l}\text { Instructors } \\
\text { receive } \\
\text { recognition } \\
\text { whenever they } \\
\text { perfume their } \\
\text { best }\end{array}$ & $4(5.20) \%$ & $9(10.80) \%$ & $10(11.90) \%$ & 23 & $42(43.90) \%$ & $35(36.30) \%$ & 77 \\
\hline $\begin{array}{l}\text { Instructors } \\
\text { views are } \\
\text { accepted and } \\
\text { appreciated }\end{array}$ & $3(4.10) \%$ & $5(6.60) \%$ & $8(9.80) \%$ & 36 & $48(49.20) \%$ & $36(37.20) \%$ & 84 \\
\hline $\begin{array}{l}\text { Instructor } \\
\text { receive equal } \\
\text { treatment from } \\
\text { management }\end{array}$ & $3(4.15) \%$ & $9(10.40) \%$ & $7(9.90) \%$ & 19 & $49(30.20) \%$ & $32(33.30) \%$ & 81 \\
\hline $\begin{array}{l}\text { Instructors } \\
\text { material and } \\
\text { social } \\
\text { problems } \\
\text { attended to at } \\
\text { all times }\end{array}$ & $3(4.10) \%$ & $5(6.20) \%$ & $10(11.80) \%$ & 18 & $35(26.00) \%$ & $47(48.50) \%$ & 82 \\
\hline $\begin{array}{l}\text { Instructor } \\
\text { have great } \\
\text { sense of self- } \\
\text { worth in the } \\
\text { Agency }\end{array}$ & $2(3.10) \%$ & $12(13.50) \%$ & $7(8.70) \%$ & 21 & $29(30.80) \%$ & $50(51.40) \%$ & 79 \\
\hline $\begin{array}{l}\text { Instructors are } \\
\text { given } \\
\text { sufficient } \\
\text { working tools }\end{array}$ & $1(2.00) \%$ & $11(12.50) \%$ & $7(8.90) \%$ & 19 & $36(27.10) \%$ & $45(46.40 \%$ & 81 \\
\hline
\end{tabular}

Discussion and Implication for Administration

Based on the findings made on monetary benefits in table 1, the positive columns for frequency and percentage distribution for salary as a motivational factor indicated the 
following scores: Strongly Agreed 11(12.25)\%, agreed 10(11.20)\% and Agreed somewhat had $9(10.80) \%$ with 30 total respondents. While the negative columns: Disagreed 42, Strongly Disagreed had 28(29.21)\% with 70 respondents respectively. This revealed that the salary earned by the Instructors in the Agency for Mass Literacy in Borno state was not enough to motivate them. This agreed with Frase (2012) who observed that salary was a strong force that kept teachers on their jobs hence it is likely to influence their performance.

Another problem revealed in this study was that, the staff in the Agency for Mass Literacy in Borno state have not been promoted for over twenty years. When promotions are done, they are based on quota system. More so, the promotions are paper promotions because the financial benefits are not implemented or attached to the new promotion. This was indicated by the following responses. The columns for positive responses indicated the scores thus, Strongly Agree 3(4.25)\%, Agreed 0(0)\% and Agreed somewhat had 2(3.50)\% with 5 respondents. While Strongly Disagreed had a score of 36(37.50)\% with 95 respondents. The study also revealed that instructors have not been exposed to training. This was indicated by the following scores in table 1 above. Strongly Agreed 2(3.80)\%, Agreed 5(6.50)\% and Somewhat Agreed 8(9.50)\% with 15 respondents, while the scores for Disagreed 30(9.50)\% and Strongly Disagreed had 55(56.50)\% with 85 respondents.

Finally, this study revealed that facilities such as buildings, infrastructural materials, office accommodation and equipment are not much available for Instructors in the Agency for Mass Literacy in Borno State. All the scores showed negative responses.

\section{Recommendations}

Based on major findings from this study, the researcher recommends the following:

1. Government should ensure welfare packages for instructors. These include monetary benefits such as attractive remuneration, traveling allowances, gratuities, bonuses and retirement allowances. The non-monetary benefits include health care for instructors and their sick families, maternity and annual leave, study leave, insurance policies against accidental death while on duty, security with regards to dismissal and retirement. The monetary benefits could be extended to include for the provision of adequate infrastructural materials namely: Primers, note books, instructors manual, chalk/white board markers, duster, black/white board and other equipment necessary for learning. It could also include arrangements for professional growth and selfactualization, improved condition of service compared to those of their counterparts in other sectors as this will motivate them towards teaching if social prestige is attached to the teaching profession.

2. The Administrators to ensure the following non-monetary benefits to Instructors: good working relationship between the Principal and the Instructors i.e.

- Sharing in policy and decision making

- Procuring sufficient working tools for Instructors

- Assigning Instructors a reasonable work load

- Being attentive to Instructors' material and social problems

- Listening and appreciating Instructors' views

- Treating Instructors impartially. 


\section{References}

Essa, D. (2010). Organizing for Effective Early Childhood Programmes. Cambridge: Havard University Press.

Frase, E. (2012). Effects of Teaching Rewards on Recognition and Job Enrichment. Journal of Education Vol 83, 53-57.

Justine, N. (2011). Motivational Practices and Teachers' Performance in Jinja Municipality Secondary Schools, Jinja District, Uganda. Online Submission.

Maslow, A. H. (1943). A theory of human motivation. Psychological review, 50(4), 370.

Wilson, K. (2013). Individual Teacher Incentives and Student Performance, Journal of Public Economics 91 901-914. Journal

Zablon M.O, Benson O\&.Pamela R (2016), Motivational Factors Influencing Teachers Job Performance in Pre-School Centres Kenya. International Journal of Innovative Research and Development vol.5 Issue 5 ISSN 2278 - 0211 (Online). 